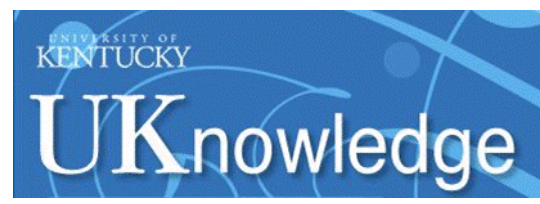

University of Kentucky

UKnowledge

\title{
Stability of Alpine Meadow Ecosystem on the Qinghai-Tibetan Plateau
}

Huakun Zhou

Chinese Academy of Sciences, China

Xinquan Zhao

Chinese Academy of Sciences, China

Li Zhou

Chinese Academy of Sciences, China

Wei Liu

Chinese Academy of Sciences, China

Yingnian Li

Chinese Academy of Sciences, China

See next page for additional authors

Follow this and additional works at: https://uknowledge.uky.edu/igc

Part of the Plant Sciences Commons, and the Soil Science Commons

This document is available at https://uknowledge.uky.edu/igc/21/1-6/21

The XXI International Grassland Congress / VIII International Rangeland Congress took place in Hohhot, China from June 29 through July 5, 2008.

Proceedings edited by Organizing Committee of 2008 IGC/IRC Conference

Published by Guangdong People's Publishing House

This Event is brought to you for free and open access by the Plant and Soil Sciences at UKnowledge. It has been accepted for inclusion in International Grassland Congress Proceedings by an authorized administrator of UKnowledge. For more information, please contact UKnowledge@lsv.uky.edu. 


\section{Presenter Information}

Huakun Zhou, Xinquan Zhao, Li Zhou, Wei Liu, Yingnian Li, Song Gu, and Xinmin Zhou

This event is available at UKnowledge: https://uknowledge.uky.edu/igc/21/1-6/21 


\section{Stability of alpine meadow ecosystem on the Qinghai-Tibetan Plateau}

ZHOU Huakun, ZHAO Xinquan ,ZHOU Li, LIU Wei, LI Yingnian, Gu Song and Zhou Xinmin Northwest Plateau Institute of Biology, Chinese Academy of Sciences, Xining810001 China.E-mail :qhzhhkyahoo .com . cn

Key words : alpine meadow, stability, coefficient of variance, ecosystem diversity, net primary production, precipitation, temperature

Introduction The stability of grassland ecosystem is one of the most important topics in modern ecology (Bai et al .2004; Tilman \& Downing 1994). However, little relevant information is available for the alpine meadow on the Qinghai-Tibetan Plateau (Zhao \& Zhou, 1999). In this paper, we examined the ecosystem stability and its sensitivity to environmental variations in an alpine meadow using the quantitative methods .

Material and methods In this study, air temperature and precipitation were measured by regular meteorological methods. The above-ground net primary production was measured by the harvest method. The annual variations of precipitation and mean air temperature from 1957 to 2000 , and the above-ground net primary production of the K. humilis meadow from 1980 to 2000 w ere collected.

In this paper,

$\mathrm{E}=\left|\left(\frac{\Delta_{\mathrm{y}}}{\Delta \mathrm{x}}\right) /\left(\frac{-\overline{\mathrm{y}}}{\mathrm{x}}\right)\right|=\left|\mathrm{b} /\left(\frac{-}{\mathrm{x}}\right)\right|$

which can measure the stability of grassland ecosystem. When $\mathrm{E}$ does not change with $\mathrm{x}$ or time $(\mathrm{t})$ in a given period, the $\mathrm{E}$ is constant. The constant E means the measurement of system stability of abiotic factor. Furthermore, it is easy to compare each other because the parameters are dimensionless .

Results and discussion Comparison of alpine meadow ecosystem stability with other five natural grassland ecosystems in Israel and southern Africa indicates that the alpine meadow ecosystem on the Qinghai-Tibetan Plateau is the most stable ecosystem . The alpine meadow ecosystem with relatively simple structure has higher stability, which indicates that community stability is not only correlated with biodiversity and community complicity but also with environmental stability. The high stability of the alpine meadow ecosystem may be resulted also from the adaptation of the ecosystem to the alpine environment .

Conclusions In this study, we use the coefficients of variation (CV) and stability (E) obtained from the Haibei Alpine Meadow Ecosystem Research Station to characterize the ecosystem stability. The results suggest that the net primary production of the alpine meadow ecosystem was more stable $(\mathrm{CV}=13.18 \%)$ than annual precipitation $(\mathrm{CV}=16.55 \%)$ and annual mean airtemperature $(\mathrm{CV}=28.82 \%)$. The net primary production $\mathrm{w}$ as insensitive either to the precipitation $(\mathrm{E}=0.0782)$ or to air temperature $(\mathrm{E}=0.1113)$. In summary, the alpine meadow ecosystem on the Qinghai-Tibetan Plateau is much stable .

\section{References}

Tilman D , Downing J A . (1994) . Biodiversity and stability in grasslands . Nature, 367 :363-365 .

Bai Y F, Han X G, Wu J G, et al . (2004). Ecosystem stability and compensatory effects in Inner Mongolia grassland. Nature, $431: 181-184$.

Zhao X Q ,Zhou X M . (1999) . Ecological basis of alpine meadow ecosystem management in Tibet : Haibei Alpine Meadow Ecosystem Research Station. Ambio ,28:642-647. 